\title{
Marketing Technologies in Higher Education for Identifying the Needs of Consumers in Lifelong Learning
}

\author{
Oksana Khilukha ${ }^{1}$, Lubov Lipych ${ }^{1}$, Myroslava Kushnir ${ }^{1} \&$ Alla Fatenok-Tkachuk ${ }^{1}$ \\ ${ }^{1}$ Lesya Ukrainka Eastern Europen National University, Ukraine \\ Correspondence: Oksana Khilukha, Lesya Ukrainka Eastern Europen National University, Ukraine
}

Received: March 30, 2020

Accepted: May 21, 2020

Online Published: October 14, 2020

doi:10.5430/ijhe.v9n6p298

URL: https://doi.org/10.5430/ijhe.v9n6p298

\begin{abstract}
Ukraine has created a competitive market of educational services, the supply of which has made a tremendous surge in the last 10 years. Trends in the development of higher education indicate that the decline in the number of student leads to a reduction in the number of higher education institutions, yet there is still a need to maintain highly professional teaching staff. The analysis of statistics shows that this tendency is common for most of the Eastern European countries. One way to improve the situation in higher education is to explore non-traditional educational avenues such as lifelong learning. This article presents the results of marketing research of consumer needs in continuing education. It was concluded that the use of Internet marketing technologies, in particular the content marketing, provide the maximum advantages to deal with the needs consumers in educational services.
\end{abstract}

Keywords: marketing technologies, content marketing, educational services, lifelong learning, consumers of educational services, universities education offers

\section{Introduction}

Demographic changes and new developments in the labor market imply the need for continuous professional improvement and updating of competences, that allow employees to quickly adapt to new conditions and expectations of employers in all areas of the economy. As a result of growing internationalization and the introduction of new technologies, the nature of work is changing dramatically (Brynjolfsson \& McAfee, 2011; Rotman, 2013). Employer requirements in almost all industries are increasing and a university knowledge is no longer a lifeline for career advancement.

The idea of continuing education and lifelong learning is a key requirement in the age of knowledge and the formation of an information society (see e.g. Jarvis, 2007). Lifelong learning is a personal choice so employees must have some motivation to take actions. The reasons for continuing job-related training are: new knowledge, productivity increasing, higher earnings, employer requirements, finding a better place to work (Medel-Añonuevo, Ohsako \& Mauch, 2001). The aim of this study is to research the marketing of consumers' needs in educational services, with the development of relevant educational programs and formation of marketing tools in the higher education management system.

In their seminal book 'Strategic Marketing for Educational Institutions', Kotler and Fox (1995) define the educational service marketing as 'the research, planning, implementation and control of carefully formulated programs designed to elicit voluntary exchange of values with target markets to achieve the aspirations of educational institutions' (Kotler \& Fox, 1995, c.7). Research by Belousova (2015) stated that the essence of the educational services marketing was the maximum accounting and satisfaction of the customers' needs: for the individual it means obtaining education, for enterprises and other organizations it lies in the growth of human resources, for society it implies the expanded reproduction of aggregate personal and intellectual potential. The achievement of these goals are ensured by the interaction of all parties. Mohylova and Reshetnikova (2016) examined the current market of educational services in Ukraine and leading European countries, by identifying the differences of financial expenditures and provided recommendations on the development of research activity in universities through the creation of high-level industrial research centers. It can be argued that the complexity of marketing functions should be assigned to the appropriate department of the university. Obolenska (2001) formulated and theoretically substantiated the concept of socially responsible marketing in the sphere of education, in the transformational period in Ukraine as combining possibilities of modern marketing methods, tools and new 
information technologies. Unlike the marketing of goods and most services, marketing in the education field creates a special relationship with the end-user personality, since it actively participates in the process of providing educational services that focus on personality transformation, which radically changes the content and nature of marketing activities and contributes to the growing need for educational services.

Concurrently, the dynamism and continuous development of the higher education system particularly in lifelong learning, requires the continued search and understanding of Ukrainian realities. Therefore, the aim of this study is to explore the marketing research of the consumers' needs in continuing education and to develop marketing technologies to introduce new educational offerings for higher education institutions.

\section{Literature Review}

The concept of 'lifelong learning' was introduced in 1965 by Lengrand at the UNESCO Forum. The ideas proposed put the person's competence at the center of social development, for which the State must create all the necessary conditions for the constant development of the abilities throughout life. The global concept of 'world unity' according to which all parts of our civilization are interconnected and interdependent, has become the impetus for the continuing education theory (Lengrand, 1970). Significant contribution to the development of the theory of continuing education was made by Dave (1976) who interpreted continuous education as the process of improving personal social and professional development throughout the life cycle of an individual, in order to improve the quality of life of both people and teams. Dave (1976) also identified 25 traits that characterize continuing education among which the most important are: enrollment in lifelong learning; understanding of the educational system as a whole, which includes preschool education, primary, re-education, parallel education and unites, integrates all its levels and forms; inclusion in the education system, in addition to educational institutions, formal, non-formal and non-institutional forms of education.

A considerable amount of scientific works has been published on the problem of lifelong learning (Field, 2000; Knapper \& Cropley, 2000; Jongbloed, 2002; Jarvis, 2007). However, as Edwards (1995) pointed out, scholars still do not have a single definition of 'continuous learning' and nowadays a whole 'conceptual sphere' exists. Lifelong learning is most commonly interpreted as the activity of both the state and the individual to obtain early childhood education until retirement for self-realization in the process of achieving life success (Modyanova, 2011; Shultz, 1968).

The study of the key needs of potential participants in continuing education at universities is the basis for determining the services needed by consumers. In order to take the full advantage of existing potential, educational institutions must focus their marketing efforts on eliminating or reducing barriers that hinder lifelong learning, change the views and attitudes of potential participants to this type of education, focus on the importance of the benefits of the offer or the increased costs associated with a lack of further education. But above all, much more attention should be paid to holistic, positive motivation for lifelong learning.

Marketing of educational services is a set of actions aimed at creating, supporting or changing the behavior of the target audience in relation to these services and their subjects. In1964 McCarthy proposed the 4P model - a marketing complex consisting of such elements as product, price, place (distribution) and promotion. The marketing complex took into account the peculiarities of the service industry was first proposed by Booms and Bitner (1981) where they proposed to supplement the marketing complex with three additional Ps: people, processes and physical evidence. In addition to the conventional 4P formula, Lauterborn (1990) offered the 4Cs marketing mix involving shifting the focus from seller to consumer, the elements of which are: 'customer wants and needs' - the consumer wishes and needs, 'cost to satisfy' - the buy spending, 'communication' - information exchange, 'convenience to buy' - consumer benefits (Tultayev, 2012). Chekitan and Schultz (2005) proposed another model as an alternative to the 4P and called it the SIVA model: Solution, Information, Value, Access.

According to Olshantseva and Britchenko (2017) the domestic marketing of educational services in Ukraine is characterized by several basic models of its development over the last decades. At the end of the twentieth century the Ukrainian education market was dominated by a traditional manufacturer-oriented education model. Universities designed their curricula and defined the services they provided based on the resources available to them. The state was the main customer, source of funding and sole consumer of trained professionals. This orientation led to contradictions: knowledge was provided but that did not fully meet the real consumers' demands or their future practical activities (Olshantseva \& Britchenko, 2017).

The second model of marketing in education is the active involvement of intermediaries who use the technology and actively provide information on educational services. Various consortia as intermediaries offering programs of 
foreign universities on the national market on the rights of their representatives. Such intermediary organizations study in detail the demand for educational services both in their own country and in Ukraine. Information on the preparation level of the university entrants allowed them to successfully select students and to adapt their programs to the specific conditions of the national market (Belousova, 2015). In recent years with the development of modern information technology the initiative has moved to the consumer of educational services. As a result, a third model of the market for educational services fully focused on the consumer was formed. Service providers must tailor their resources to the consumers' needs and other target audiences of higher education institutions: entrants, students, employers, public education authorities and the general public. Therefore, the customer-centric 4C and SIVA concepts would appear to be most suitable for the educational services industry.

Formally the functions of product marketing and service marketing coincided, including market research, planning, organization, control and audit. The differences are found in the content of each of these functions since the educational service as a subject of marketing efforts is quite specific. It is suggested to carry out marketing analysis according to the following scheme: information collecting from consumers, its processing and analysis, subsequent changes according to the data received from consumers, transmission of advertising information to consumers using integrated channels of marketing communications (Kostiuchenko, 2014).

\section{Method}

In order to identify the perception of 'traditional education' and 'lifelong learning' by consumers, on-line invitations to participate in the study were sent to employees of business organizations of Western Ukraine. 706 respondents were interviewed personally and on-line about the differences between traditional education and lifelong learning. The participants were categorized into four groups: university graduates who started their professional activities (less than 5 years of employment), employees with extensive professional experience (more than 10 years of employment), owners of businesses and business executives. The questionnaire covered the following topics: (1) General characteristics of traditional education and lifelong learning, (2) Purpose and objectives of traditional education and lifelong learning, (3) Identification of adults' real needs to enhance their competences, (4) Procedures and implementation measures of lifelong learning, (5) Potential barriers to the emergence of new forms of learning, (6) The potential and professionalism of higher education institutions and other institutions providing educational services, (7) Quality of educational programs and teaching in higher education institutions and other institutions that provide educational services.

To characterize the educational institutions and the quality of their teaching staff, publicly available information from the following institutions was used:

- State Statistics Service of Ukraine - data on the number of students, the quantitative and qualitative composition of the teaching staff;

- Główny Urząd Statystyczny (Poland) - data on the proportion of foreign students from the total number of higher education applicants in Poland and the number of students per scientific and pedagogical worker in Poland;

- Eurostat - number of students and population in Eastern Europe.

\section{Results}

Ukraine's growing economy needs highly qualified professionals and the level of its education system must meet the highest world standards. However, there is a low competitiveness of Ukrainian graduates in the European market. Some scholars and experts in higher education link such situation to the lack of new educational programs that meet the needs of current economic development (Yastrubskyi, 2018; Obolenskaya, 2001). The existing planning system of specialist's training does not correspond to the demand for them. As a result the inability to employ in a profession leads to an exacerbation of social tensions, the need for retraining or a second education. Terovanesov (2014) attributes the gap between higher education and economic development to the absence of market mechanisms for the coordination of the educational services and the needs of the economy in Ukraine.

The demographic situation has a significant impact on the development of higher education. Analysis of the statistical data from the website of the State Statistics Committee of Ukraine showed a steady decline in the total number of students in Ukraine higher education institutions during the last decade. According to statistics in the 2005/6 academic year there were 951 universities in Ukraine with the total number of students over 2.7 million that corresponded to 578 students per 10,000 population. During the next 11 years the number of students per 10 thousand of population in Ukraine has decreased more than 1.5 times to 372 in the 2016/2017 academic year (Statistical Yearbook of Ukraine, 2017). The similar situation was observed in most of the Eastern European countries with the decrease in number of students per 10 thousand of population during 2014-2017 years (Fig. 1). 
The exceptions are Lithuania, Latvia and Romania, where there is some growth that can be explained by migration processes.

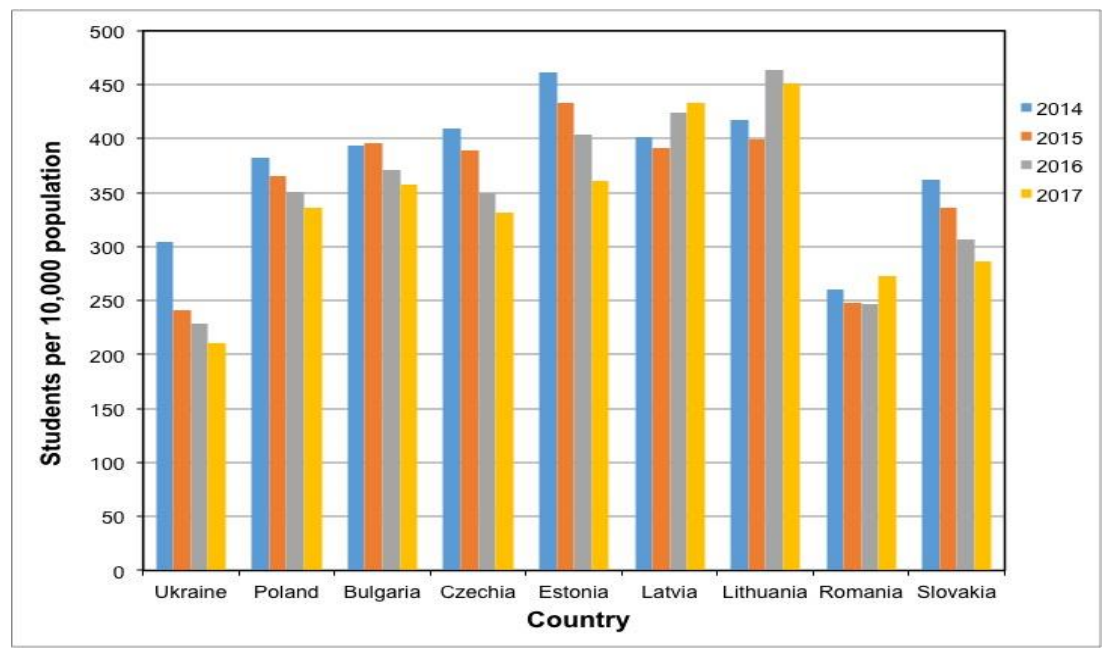

Figure 1. Number of students per 10,000 populations in Ukraine and Eastern European countries during 2014-2017 years

The demographic component impacts the situation in higher education not only in Ukraine. The Polish government is trying to cope with the demographic decline through the introduction of appropriate programs such as the National Health Program for 2016-2020 that included a public birth campaign. The Polish government also implemented a number of steps to rescue the higher education system that resulted in a significant number of foreign students among the total number students in Polish higher education institutions. Currently, about 60,000 foreign students study at Polish universities. Half of them are citizens of Ukraine. The rapid growth in the number of Ukrainian students in Polish universities took place in 2014-2019. According to the educational foundation "Perspectives", such increase is the result of a ten-year advertising campaign by Polish universities in Ukraine (Radio Liberty, 2020).

Despite of the decline in the number of students and aggravation of competition in the higher education system, the quality of the teaching staff in higher education institutions in Ukraine is improving. According to the Ministry of Education of Ukraine, during 2012-2017 years 6428 people defended dissertations for Doctor of Science degree and 15086 defended dissertations for Doctor of Philosophy degree, which is 1.6 and 1.5 times more than in 2007-2012 years, respectively. These statistical data confirm the existence of highly qualified academic potential in higher education system of Ukraine (Vox Ukraine, 2018).

As shown in the above analysis, demographic situation affects the number of students and causes the reduction in the number of educational institutions and teaching staff that is a common trend in many European countries. One way to improve the situation in higher education and to maintain the existing teaching staff is by looking into non-traditional education such as lifelong learning.

Continuing education is a set of ways and forms of acquiring, deepening and expanding basic education, professional competence and personality culture (Jarvis, 2007). For every person continuing education is the process of forming and meeting their cognitive and spiritual needs, developing abilities in a network of educational institutions or through self-education. European higher education institutions included lifelong education as one of the goals in the reform of higher institutions that was discussed and accepted in Bologna in 1999 (Bologna declaration, 1999). However, analysis of the higher education policies in Germany, France, Italy and the UK shows that countries consider quite different strategies to lifelong learning in higher education (Jakobi \& Rusconi, 2009).

The essence of the educational services marketing is to maximize the satisfaction of the individual needs of the consumers of educational services for personal and professional growth and enhancement of the personal value resulting in the reproduction of the overall intellectual potential in society. Therefore, a thorough examination of the consumers as the direct recipients of educational products is the basis of education marketing. In a context where the service is a product, the recipients of the university's educational offer in Western Ukraine region were asked to compare the concepts of traditional education and lifelong learning and to distinguish common and distinct features between them. Traditional education was most often associated with the acquisition and expansion of knowledge by 
all participants. Associations also included professional development, advanced training, professional development. Other types of associations included meeting new people and sharing experiences. The participants viewed lifelong learning as an extension of the individual learning process. This term was perceived as less formal and not related to the traditional learning process.

Most participants of the survey associated traditional education with formal education while recognizing lifelong learning as less formal educational service. Respondents pointed also to greater positive associations with lifelong learning. Although traditional education was mostly required it was not enough for continued professional growth.

The implementation of the idea of lifelong learning requires changes in the approaches to education marketing technologies offered today by higher education institutions. Universities are interested in the development of lifelong learning since it is organized on the existing educational infrastructure. However, it is preceded by marketing research aimed at diagnosing adults' real needs for increasing their competencies and enhancing knowledge. It should be pointed out that an attractive offer requires taking into account market expectations, identifying skills gaps, knowledge of learning motives, and identifying related benefits and barriers. In the present study, an attempt was made to identify an interest in the preparation and enhancement of competencies among the four groups of respondents identified as crucial to the development of the university's educational offers. These four groups included university graduates who started their professional activities, employees with extensive professional experience, business owners, and business executives. In total, 706 respondents were interviewed. The vast majority of respondents (98.3\%) said that they potentially need a further education and improvement of their competences with $70.0 \%$ responded as 'probably yes' and $28.3 \%$ said 'yes'. At the same time, $82.0 \%$ of respondents indicated that they are engaged in activities related to competence development and knowledge expansion. Among the selected forms of education the following ones prevailed: self-study (books, magazines, online courses) $-96.3 \%$ of respondents, courses/training organized by universities $(74.5 \%)$, courses/training organized by other educational organizations $(24.3 \%)$ and on-the-job training courses/training $(41.1 \%)$. More than half of the respondents had already participated in seminars and conferences (55.6\%) and four out of ten (40.9\%) had used courses/training online. Respondents also referred to other types of education: exchange of experience in groups of workers working in the same field, professional and social conferences.

In another part of the study the participants assessed their interest in improving competencies. To deepen the topic they were asked to name the reasons for such increase. In their responses participants pointed to the need for lifelong learning due to the rapid changes in the market environment and the demands of the labor market, growing awareness. The 'lifelong learning' was connected with greater availability of different forms of education. Some participants emphasized the increasing openness to education among the adult people. Others said that interest in enhancing competencies was 'not an age but a situation' (there are people that are open to everything new from the childhood, others in their nature, resistant to all changes). Respondents also indicated that the greatest interest in education was due to technological development and introduction of new online tools. They emphasized that universities have a high potential to implement different forms of education and, when it comes to lifelong learning, education institutions are better placed to coordinate training programs with business partners, through contacts with the business world. The respondents in all groups pointed out to the benefits of the university's educational offer due to the greater trust in them and the guarantees of introduction of new programs. All participants found as very important factors being able to meet and connect with others. No less attention was paid to the exchange of experience as well as social aspects. Participants in the group "workers with extensive professional experience - 40 +' considered training as a process of broadening their horizons and meeting their own interests. In such group the motivation for learning is also the need to gain a sense of independence, employees want to be self-sufficient for as long as possible. In the young workers group much attention is paid to the importance of obtaining certificates.

To assess the benefits of lifelong learning the respondents were asked to name at least one such benefit. The most commonly cited advantages are related to: continuation of functioning in the labor market (higher, better position in the labor market, higher competitiveness, faster adaptation to the demands of the labor market, flexibility, expansion of competences); general personality development and self-esteem (self-fulfilment at work, satisfaction, confidence); updating of knowledge (availability of up-to-date knowledge, study of new regulations, scientific and business trends); economic sphere (increase of earnings, possibility of change of work for higher salary).

Examination of universities lifelong learning education services from a marketing perspective requires identification of potential barriers to perceiving the proposed forms of learning. It is important to understand the reasons why some people do not study and to identify factors that limit their ability to do so. According to the survey results, the main reasons for the low demand for lifelong learning were the following: lack of finances (participants emphasized the 
importance of education funded by various foundations); lack of free time or unwillingness to spend their free time; the content of educational services offered that do not meet real needs; lack of motivation and fear of the unknown.

\section{Discussion}

The education system that existed Ukraine does not fully meet the needs of the present and will not be acceptable in the future. That is why the modernization of education in Ukraine should be aimed at compliance with the basic principles of market economy, the transformation of education into the most important resource of personal and social development, into a resource of implementation of the national and universal values. Institutions pursuing a strategy for the development of education should think beyond the boundaries of traditional primary and vocational training as well as formal education. They should rethink the idea that basic education provided at a young age is sufficient preparation for lifelong work and even more so for life success.

The introduction of a marketing system in a higher educational institution means to implement a market relation philosophy in the education system and to ensure the interaction of consumers, intermediaries and producers of educational services as well as educational products in conditions of the market and free choice. Marketing orientation of the institution is the first stage for the creation of a marketing department, which will perform the functions of developing and implementing measures for an appropriate image of the institution. The functions of such department should also include identification of educational services that are and will be in demand in the market, conducting marketing research and projects. The marketing department will also develop justification of prices for educational services, taking into account the size and dynamics of demand, control over the implementation of the developed recommendations by other units of educational institution. It is recommended to direct further research into the scientific and practical problem of marketing development in the field of education services. Particular attention should be focused on emerging marketing technologies, in particular content marketing, which operates within Internet marketing and is an effective tool for examining the needs of consumers of educational service.

Today, the success of higher education institutions on lifelong learning offers is virtually impossible without the use of the Internet. In this context, it is of particular relevance to explore new opportunities for marketing activities with its use, including context marketing. Content marketing is a set of marketing techniques based on the creation and/or dissemination of useful information for the consumer in order to win the trust and attract potential customers. In general, content marketing is the distribution of such information that will make a potential entrant pay attention to a university's offer and likely to become an actual student. Information or content can be of any format, text, graphics, audio-visual, etc. Channels and ways of distribution are diverse; their number is limited only by the imagination of the marketer and common sense. Content marketing aims to build a long-lasting reputation for the institution. Content value and relevance are the main features that make it different from spam. The essence of content marketing is to create valuable content for potential consumers: reviews, jokes, or useful tips that can get a user's trustworthy placements. The goal of content marketing is to increase site traffic and, accordingly, it's rating to increase the demand for educational offers. The form and presentation of the message should be also aimed at increasing the level of customer loyalty due to the value and relevance of information.

The peculiarity of content marketing is that it is more marketing than content. Therefore, the first step is to select the consumers of the information. Content should be communicated to as many members of target audiences as possible. Content marketing needs to be integrated into the overall marketing strategy of the university. This is the art of communicating with potential customers and target audience. The essence of the strategy is to create a positive emotional connection, to provide people with interesting and useful information. Expert positioning is a spectacular opportunity to stand out from the large number of competitors who also offer training programs. Content marketing belongs to a class of methods that give minimal effect at the beginning of use. But the effect accumulates and over time we get more and more results with a minimum of extra effort. This is noticeable, for example, when promoting a university blog or spinning it on social networks. Therefore, content marketing is about creating quality, engaging, and useful content for the target audience, as well as distributing it through a variety of channels. The main task of content marketing is to communicate with the audience, disseminate information about the institution, new and existing educational offers, establish trusting relationships and ensure loyalty from potential customers.

Common communication problems are the study of communications itself, their frequency, format/channel, relevance, comprehensibility, dialogue (feedback), and visualization (Tertichnyi, 2017). Three questions are applied to overcome the mentioned shortcomings:

- What is the target audience? 
- What should the target audience know about the institution (s) (education programs)?

- What should the target audience do (real action)?

Using such issues as a part of communication activities will allow preparing more straightforward and clear documents (messages) that will reach clearly defined intentions. The developer of the content needs to be constantly on the lookout for new forms, expanding traditional content ideas to maximize the response of the target audience.

Effective content management tools include:

1. Numbered lists (for example, '5 components ...', '10 simple ways ...'). Such lists are often popular with social media readers.

2. Photo reporting as a powerful way to convey the content of an event; it must have at least five high-quality photo, each of which should fill the full width of the page.

3. Research results as a brief overview of the report should contain at least five of the most important emphases.

4. Help Stories as a story about the people to whom the product has become of help (it's important such stories to be empathetic ones).

5. Thankful customer reviews, interviews.

6. New mobile and media content. While launching new content it is advisable to accompany it with a description (for example, write a post that would cover new content).

Jongbloed (2002) developed the so-called "golden formula" of social content components with the following ratio: educational (25\%), image (40\%), advertising (5\%) attractive (30\%). Educational analysts emphasized that universities need to restructure not only programmatic offerings and presentations, but also rework their business concepts, that is, a way to create value and maintain their competitive advantage over other educational providers. The business concept should be as student-centered as possible (Jongbloed, 2002).

The essence of marketing educational services lies in the maximum satisfaction of the customers needs. In order to achieve such goal, the interaction of all participants, in particular educational organizations and customers, is required. Constantly updating educational offerings for some and competencies for others is a prerequisite for keeping up with the pace of change, understanding the world around us and solving problems in an ever-changing reality. Lack of motivation, willingness and/or ability to constantly improve and update educational services means lack of professional flexibility and adaptability. This determines the low cost of the labor market and, in the long run, impedes active participation in a knowledge-based public life.

Universities need to respond positively to the growing expectations of the market environment for increasing the supply of training, expanding and diversifying short forms such as courses, training, etc. They must become the engine of economic development, the depository and creator of modern knowledge and didactic innovation.

\section{Acknowledgments}

The research was funded by the Ministry of Education and Science of Ukraine. No potential conflict of interest is reported by the author.

\section{References}

Belousova, S. V. (2015). Marketing of educational services. Business Navigator, 1(36), 39-43. https://doi.org/10.1108/JBS-07-2014-0084

Bologna Declaration. (1999). Joint declaration of the European Ministers of Higher Education. Bologna, June 19. Retrieved from http://www.ehea.info/page-ministerial-conference-bologna-1999

Booms, B. H., \& Bitner, M. J. (1981). Marketing strategies and organization structures for service firms, in Donnely, JN and George, WR (Eds), Marketing of Services, American Marketing association, Chicago, IL.

Borden, N. H. (1964). The concept of the marketing mix. Journal of advertising research, 4(2), 2-8. Retrieved from https://www.commerce.uct.ac.za/Managementstudies/Courses/BUS2010S/2007/Nicole\%20Frey/ Assignments/Borden,\%201984_The\%20concept\%20of\%20marketing.pdf

Brynjolfsson, E., \& McAfee, A. (2011). Race Against the Machine: How the Digital Revolution is Driving Productivity, Accelerating Innovation, and Irreversibly Transforming Employment and the Economy. Digital Frontier Press.

Chekitan S. Dev, C. S., \& Schultz, D. E. (2005). A customer-focused approach can bring the current marketing mix 
into the 21st century. Marketing Management, 14(1), 18-24.

Dave, R. H. (1976). Foundations of lifelong education: Some methodological aspects. In Foundations of lifelong education (pp. 15-55). Pergamon. https://doi.org/10.1016/B978-0-08-021192-3.50007-1

Dev, C. S., \& Schultz, D. E. (2005). Simply SIVA. Marketing Management, 14(2), 36-41. Retrieved from https://docplayer.net/39789152-S-i-m-p-l-y-get-results-with-the-new-marketing-mix-by-chekitan-s-dev-and-don -e-schultz-36-m-m-m-a-r-c-h-a-p-r-i-l.html

Edwards, R. (1995). Behind the Banner: Whither the Learning Society? Adults Learning, 6(6), 187-89.

Eurostat. (2018). Aggregate for European Union without UK available since April 2018.

Field, J. (2000). Lifelong learning and the new educational order. Trentham Books, Ltd., UK.

Główny Urząd Statystyczny. (2017). Infografika - Międzynarodowy Dzień Studenta 17 listopada.

Illiashenko, S. M., \& Shypulina, Yu. S. (2012). Communication effectiveness of WEB-technologies in marketing of research and educational services. Marketing and innovation management, 1, 67-77. Retrived from https://mmi.fem.sumdu.edu.ua/en/journals/2012/1/69-78

Jakobi, A. P., \& Rusconi, A. (2009). Lifelong learning in the Bologna process: European developments in higher education. A Journal of Comparative and International Education, 39(1), 51-65. https://doi.org/10.1080/03057920801936977

Jarvis, P. (2007). Globalization, lifelong learning and the learning society: Sociological perspectives. Routledge. https://doi.org/10.4324/9780203964408

Jongbloed, B. (2002). Lifelong learning: Implications for institutions. Higher Education, 44, 413-431. https://doi.org/10.1023/A:1019825803857

Knapper, C., \& Cropley, A. J. (2000). Lifelong learning in higher education. Psychology Press.

Kostyuchenko, A. M. (2014). Specificity of marketing of educational services and current problems of education in Ukraine in the conditions of market environment. Bulletin of the Donetsk University of Economics and Law, 2.

Kotler, P., \& Fox, K. F. (1995). Strategic marketing for educational institutions. New Jersey: Prentice-Hall.

Lengrand P. (1970). Introduction to Lifelong Education. Paris: The UNESCO Press, 1970. - 99 p

Mccrone, D. (2005). Cultural capital in an understated nation: the case of Scotland. The British Journal of sociology, 56(1), 65-82. https://doi.org/10.1111/j.1468-4446.2005.00047.x

Medel-Añonuevo, C., Ohsako, T., \& Mauch, W. (2001). Revisiting Lifelong Learning for the 21st Century. UNESCO Institute for Education, Hamburg (Germany). Retrieved from https://unesdoc.unesco.org/ark:/48223/pf0000127667

Modyanova, T. V. (2011). Modern concepts of formation and implementation of personnel policy. The experience of European countries and the USA. Personnel. HR management, 2, 143-149.

Mohylova, A. Y., \& Reshetnikova, I. V. (2016). Features of marketing in the educational services market. Scientific Bulletin of Uzhgorod National University, 10(2), 21-25. https://dspace.uzhnu.edu.ua/jspui/handle/lib/12207

Obolenskaya, T. E. (2001). Marketing of educational services: domestic and foreign experience. Kiev: KNEU.208. Retrieved from http://www.library.kpi.ua/recs_kpi/KMA02/94/78/10/00/KMA02.000129478.html

Olshantseva, T. O., \& Britchenko I. G. (2013). The Educational Services Competitiveness Increasing Methods of Higher Education Institutions. - I International Scientific and Practical Internet Conference "Actual issues of increasing the competitiveness of the state, business and education in modern economic conditions". - Poltava: Universities of Poltava University of Economics and Trade.

Radio Liberty (2020). Ukrainian students go to study in Poland. Retrieved from https://www.radiosvoboda.org/a/27079605.html

Rotman, D. (2013). How technology is destroying jobs. MIT Technology Review Magazine, 16(4), 28-35.

Shultz, T. (1968). Human-Capital Approach to Entrepreneurship. Agricultural Economics, 28(3), 344-350. https://doi.org/10.2307/3877178

Terovanesov, M. R. (2014). Optimization of the management system of higher education. Scientific Bulletin of Kherson State University, 9(2), 83-87. Retrieved from http://www.ej.kherson.ua/journal/economic_09/72.pdf. 
Tertichnyi, O. O. (2017). Features of Internet marketing. Economy and Society, 12, 383-385. Retrieved from http://economyandsociety.in.ua/journal/12_ukr/64.pdf.

The official website of the State Statistics Committee of Ukraine. Web URL http://ukrstat.org/uk

Tultayev, T. A. (2012). 5P, 7P, 4C: basic concepts of the marketing complex. - Center for Continuing Education. Retrieved from http://www.elitarium.ru/2012/08/29/koncepcii_marketingovogo_kompleksa.html

Vox Ukraine. (2018). Ukraine without science, or How failed the attempt of the Scientific Committee to stop the wave of fake dissertations. from https://voxukraine.org/uk/ukrayina-bez-nauki-abo-yak-provalili-sprobu-naukovogo-komitetu-zupiniti-val-fejkov ih-disertatsij

Yastrubskyi, M. (2018). Activities of higher educational institutions of Ukraine harmonious development state regulation and investment and innovation support. Lviv: publisher of Lviv Polytechnic.

Yastrubskyi, M. (2018). Harmonious Development and State Regulation of Ukraine Higher Educational Establishments Activity. [Dis. for the degree of Doctor of Economics], Lviv Polytechnic National University.

Zharaia, S. (2013). Paid educational services in the system of general educational institutions of Ukraine. Actual problems of public administration, 3, 71-75. Retrieved from http://nbuv.gov.ua/UJRN/apdyo_2013_3_21

\section{Copyrights}

Copyright for this article is retained by the author(s), with first publication rights granted to the journal.

This is an open-access article distributed under the terms and conditions of the Creative Commons Attribution license (http://creativecommons.org/licenses/by/4.0/). 